\title{
Morphodynamic simulation of sediment deposition patterns on a recently stripped bedrock anastomosed channel
}

\author{
David Milan $^{1}$, George Heritage ${ }^{2}$, Neil Entwistle ${ }^{3}$, and Stephen Tooth ${ }^{4}$ \\ ${ }^{1}$ School of Environmental Science, University of Hull, Cottingham Road, Hull, HU6 7RX, UK \\ ${ }^{2}$ AECOM, Exchange Court, 1 Dale Street, Liverpool, L2 2ET, UK \\ ${ }^{3}$ School of Environment and Life Sciences, University of Salford, Salford, M5 4WT, UK \\ ${ }^{4}$ Department of Geography and Earth Sciences, Aberystwyth University, Aberystwyth, SY23 3DB, UK
}

Correspondence: David Milan (d.milan@hull.ac.uk)

Received: 9 June 2017 - Accepted: 16 August 2017 - Published: 16 April 2018

\begin{abstract}
Some mixed bedrock-alluvial dryland rivers are known to undergo cycles of alluvial building during low flow periods, punctuated by stripping events during rare high magnitude flows. We focus on the Olifants River, Kruger National Park, South Africa, and present 2-D morphodynamic simulations of hydraulics and sediment deposition patterns over an exposed bedrock anastomosed pavement. We examine the assumptions underlying a previous conceptual model, namely that sedimentation occurs preferentially on bedrock highs. Our modelling results and local field observations in fact show that sediment thicknesses are greater over bedrock lows, suggesting these are the key loci for deposition, barform initiation and island building. During peak flows, velocities in the topographic lows tend to be lower than in intermediate topographic areas. It is likely that intermediate topographic areas supply sediment to the topographic lows at this flow stage, which is then deposited in the lows on the falling limb of the hydrograph as velocities reduce. Subsequent vegetation establishment on deposits in the topographic lows is likely to play a key role in additional sedimentation and vegetation succession, both through increasing the cohesive strength of alluvial units and by capturing new sediments and propagules.
\end{abstract}

\section{Introduction}

Many of the large rivers draining southern Africa are characterised by bedrock "macrochannels" incised $10-20 \mathrm{~m}$ into ancient planation surfaces but with variable amounts of unconsolidated sediment infill. Variations in lithology, structure, flow regime, sediment supply, and vegetation assemblages have created morphologically diverse river systems. Many rivers have been characterised by extended periods of alluviation on an historic timescale (Tooth, 2016), leading to the development of increasingly alluvial channel types with the underlying bedrock commonly masked. Alluviation is periodically interrupted by extreme flood stripping of accumulated sediment (Heritage et al., 2001), events which have also been highlighted as an important mechanism behind fluvial change and system resetting in Australian, Indian and North
American river systems (e.g. Baker, 1977; Nanson, 1986; Kale et al., 1996).

Anastomosed channels represent one of the key channel types in many mixed bedrock-alluvial rivers in the Kruger National Park (KNP), South Africa (Heritage et al., 2004). Response in these channel types is largely controlled by different magnitude flood events; alluvium and vegetation is stripped from the bedrock template during large or extreme events, and intervening building phases with lower magnitude floods allow sediment accumulation and vegetation establishment through plant succession (van Niekerk et al., 1999; Rountree et al., 2000). In van Niekerk et al.'s (1999) conceptual model, during building phases, flood deposition occurs preferentially on topographic highs on the stripped bedrock template, initiating sedimentation and vegetation establishment, while topographic lows remain relatively sediment free. To date, there has been little empirical evidence 
available to enable examination of the assumptions underlying this conceptual model. Stripping events tend to be rare, and obtaining field data on sedimentation can be difficult due to the presence of dangerous animals, dense vegetation and the large scale of the channels. Using morphodynamic modelling and field observations, this paper investigates the processes driving alluviation and bar/island development over a bedrock template, examining in particular the influence of topography on hydraulics and depositional loci.

\section{Study site}

The Olifants River is located in the southern and central part of the KNP in the Mpumalanga and Limpopo provinces of north-eastern South Africa (Fig. 1). The $54570 \mathrm{~km}^{2}$ Olifants catchment covers part of the Highveld Plateau ( 2000 $1500 \mathrm{~m}$ a.s.l.), the Drakensberg Escarpment, and the Lowveld ( $\sim 400-250$ ma.s.l.). Rainfall is greater in the highlands $\left(\sim 2000 \mathrm{~mm} \mathrm{yr}^{-1}\right)$ and declines rapidly eastwards towards the South Africa-Mozambique border $\left(\sim 450 \mathrm{~mm} \mathrm{yr}^{-1}\right)$. Although water abstractions have altered the low flows (typically $<50 \mathrm{~m}^{3} \mathrm{~s}^{-1}$ ), flood flows are unaffected, and the river remains unimpacted by engineering structures or other human activities over considerable lengths within the KNP. Thus, the river provides excellent, near-pristine sites for investigating dryland, bedrock-influenced channel dynamics.

The Olifants River in the KNP is characterised by a bedrock macrochannel up to $\sim 500 \mathrm{~m}$ wide that is incised $10-20 \mathrm{~m}$ into the Lowveld. Outside of the macrochannel, floods have a very infrequent and limited influence. The river is characterised by a high degree of bedrock influence, but the bedrock may be buried by alluvial sediments of varying thickness. The diverse underlying geology (principally basalt, with some tonalitic gneiss) results in frequent, abrupt changes in macrochannel slope and associated sediment deposition patterns, creating diverse channel types that include alluvial single-thread and braided channels, and bedrock anastomosed and pool-rapid channels (van Niekerk et al., 1995; Milan et al., 2017).

A large cyclone-driven flood event occurred in January 2012, resulting in an estimated peak discharge of between 14407 to $16772 \mathrm{~m}^{3} \mathrm{~s}^{-1}$ (Heritage et al., 2017). This flood led to extensive stripping of alluvium from the channels to reveal the underlying bedrock template. Our study focused on a $4 \mathrm{~km}$ length of stripped bedrock anastomosed channel (Fig. 1c) as this provided an opportunity to examine the processes responsible for the initiation of deposition over the stripped bedrock following the flood.

\section{Methods}

Aerial LiDAR and orthophotography was obtained on 30 May 2012 for a $50 \mathrm{~km}$ reach of the lower Olifants in the KNP. Southern Mapping Geospatial surveyed the river us-

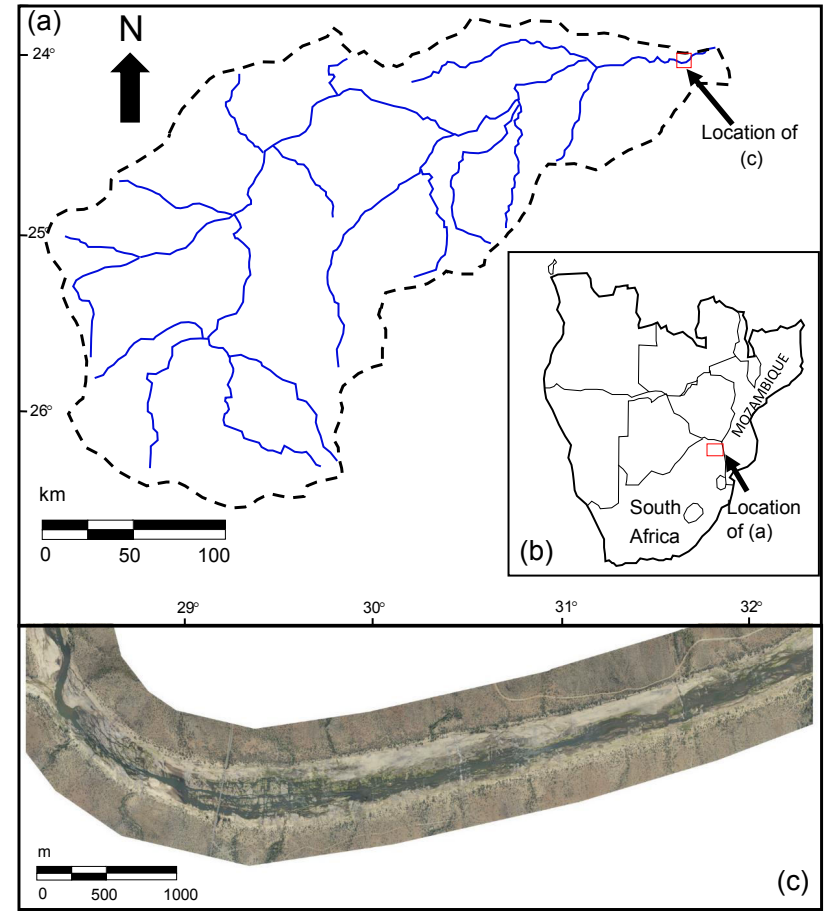

Figure 1. Olifants River catchment; (a) catchment map, (b) location in South Africa, (c) aerial photograph (May 2012) of reach in the Kruger National Park used for simulation.

ing an Opetch Orion 206 LiDAR, and a Rollei AIC with a 60 mega-pixel P65+ Phase One digital CCD, flown from a Cessna 206 at $1100 \mathrm{~m}$ altitude. To allow 2-D morphodynamic modelling, the LiDAR was degraded to $5 \mathrm{~m}$ resolution, which is typically smaller than the width of the anabranches through the bedrock. A field visit was also conducted in May 2012 to gather evidence of processes influencing fine sediment deposition and reworking along the river.

2-D flow and sediment transport modelling was undertaken to investigate hydraulic and sediment transport processes more closely for the study reach using the $2012 \mathrm{Li}$ DAR data. We used the CAESAR Lisflood morphodynamic code (Coulthard et al., 2013), with a 14 day flow time series (Fig. 2a) that included two hydrograph peaks (4500 and $2000 \mathrm{~m}^{3} \mathrm{~s}^{-1}$ ), sufficient to fully submerge bedrock highs in the channel. The model was run on the bare earth $5 \mathrm{~m}$ DEM with a Mannings " $n$ " of 0.04 , and was set to recirculate any eroded sediment. For alluvial channels, bedrock is typically at an elevation lower than the surface elevation, but here the bedrock was set to the level of the surface to produce a resistant macrochannel template. A slug of sand-size sediment $\left(D_{50}=1.4 \mathrm{~mm}\right)$ was introduced from upstream with a feed rate of between $2 \times 10^{5}$ and $90 \times 10^{5} \mathrm{~m}^{3} \mathrm{~h}^{-1}$ to reflect the fact that flows along the river are generally transport- rather than supply-limited. The aim was to investigate stage-dependent hydraulics and patterns of erosion and deposition relative to the bedrock template. Emphasis was placed on mapping 

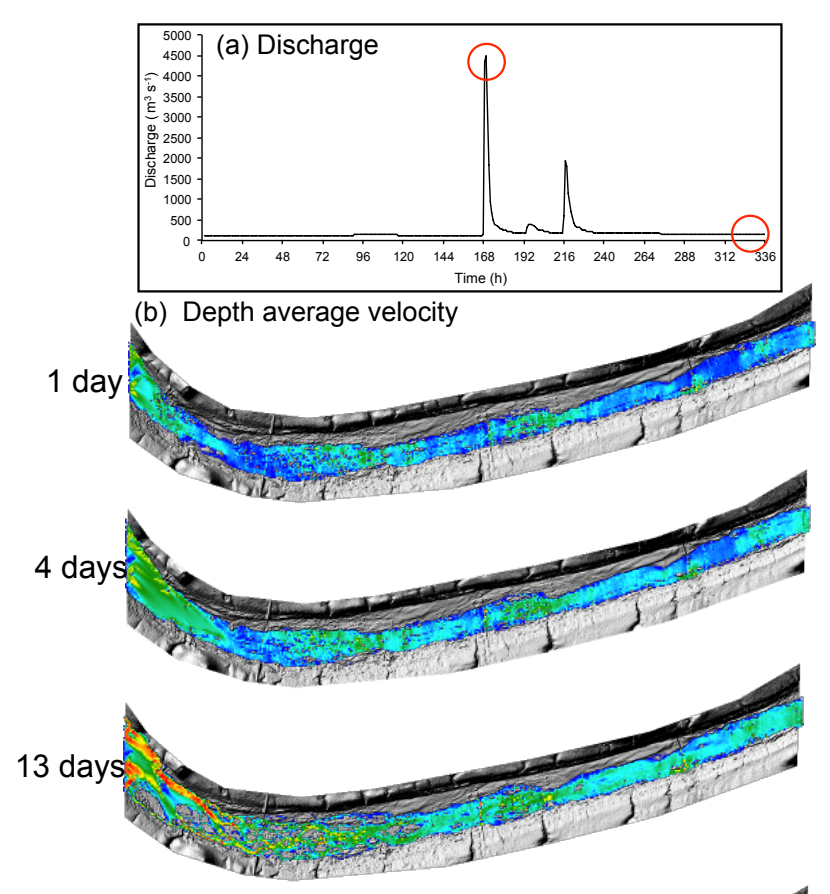

(c) Spatial pattern of sediment deposition
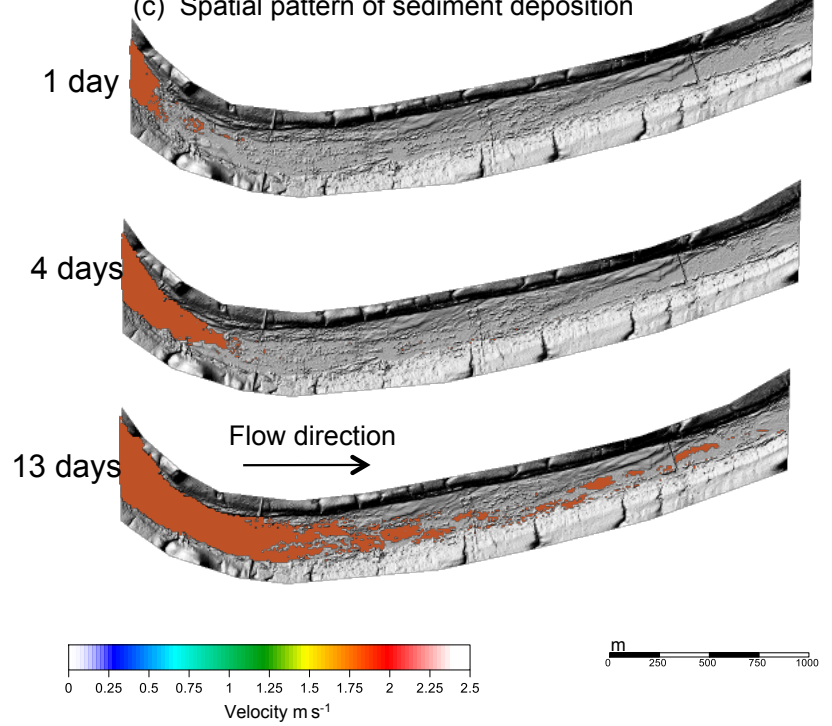

Figure 2. CAESAR-Lisflood simulations: (a) Discharge timeseries with 4500 and $200 \mathrm{~m}^{3} \mathrm{~s}^{-1}$ flows highlighted; (b) depthaveraged velocity patterns, (c) spatial patterns of deposition as a sediment slug (orange shading) is dispersed through the model domain.

depositional loci and identifying their topographic and hydraulic controls. For each $5 \mathrm{~m}$ pixel on the DEM, comparisons were made between the detrended bedrock template elevations and: (1) sediment thicknesses deposited at the end of the model run; (2) velocities for a high $\left(4500 \mathrm{~m}^{3} \mathrm{~s}^{-1}\right)$ and low $\left(200 \mathrm{~m}^{3} \mathrm{~s}^{-1}\right)$ discharge.

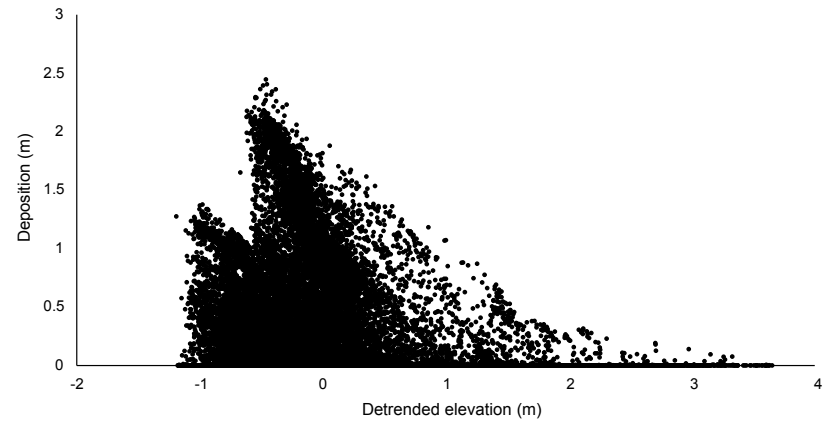

Figure 3. Sediment thicknesses for each $5 \mathrm{~m}$ pixel of study reach versus detrended bed elevation.

\section{Results}

\subsection{Spatial patterns of deposition and channel development}

Three snapshots taken over the 14 day duration of the simulation are shown in Fig. 2b-c. Early in the simulation, flow is running predominantly over the bedrock template, and for the lower discharges is controlled by the anastomosed channel network etched into the bedrock. Gradually, the sediment that is fed into the model is distributed downstream, most markedly following the peak discharge of $4500 \mathrm{~m}^{3} \mathrm{~s}^{-1}$. After 13 days, the upstream most $800 \mathrm{~m}$ of the reach is fully alluvial, and a braided channel network is evident, largely independent of the anabranches in the bedrock beneath (Fig. 2c; 13 days). Although it is likely that the model run time was insufficient to fully disperse the slug supplied to the reach, field observations show that this channel type is becoming more common on the river and these results suggest that superficial braiding will persist in the short to medium term. Farther downstream, patches of sediment clearly accumulate as lobate barforms (Fig. 2c; 13 days); field observations show that such features are indeed present along the river and are becoming colonised by Phragmites spp.

\subsection{Simulated sediment thicknesses}

Sediment thicknesses for each $5 \mathrm{~m}$ pixel of a detrended raster DEM covering the barforms and exposed bedrock areas were extracted. To identify the association between sediment thickness and topography, the bedrock template DEM was detrended to remove any downstream slope trend. Detrended elevations for each $5 \mathrm{~m}$ pixel were then retrieved for the same loci as the sediment thicknesses.

The resultant plot (Fig. 3) clearly shows greater sediment accumulation in areas of negative bed topography i.e. topographic lows. The sediment thickness data therefore appear to suggest that these barforms are initiated by the infilling of bedrock topographic lows. 


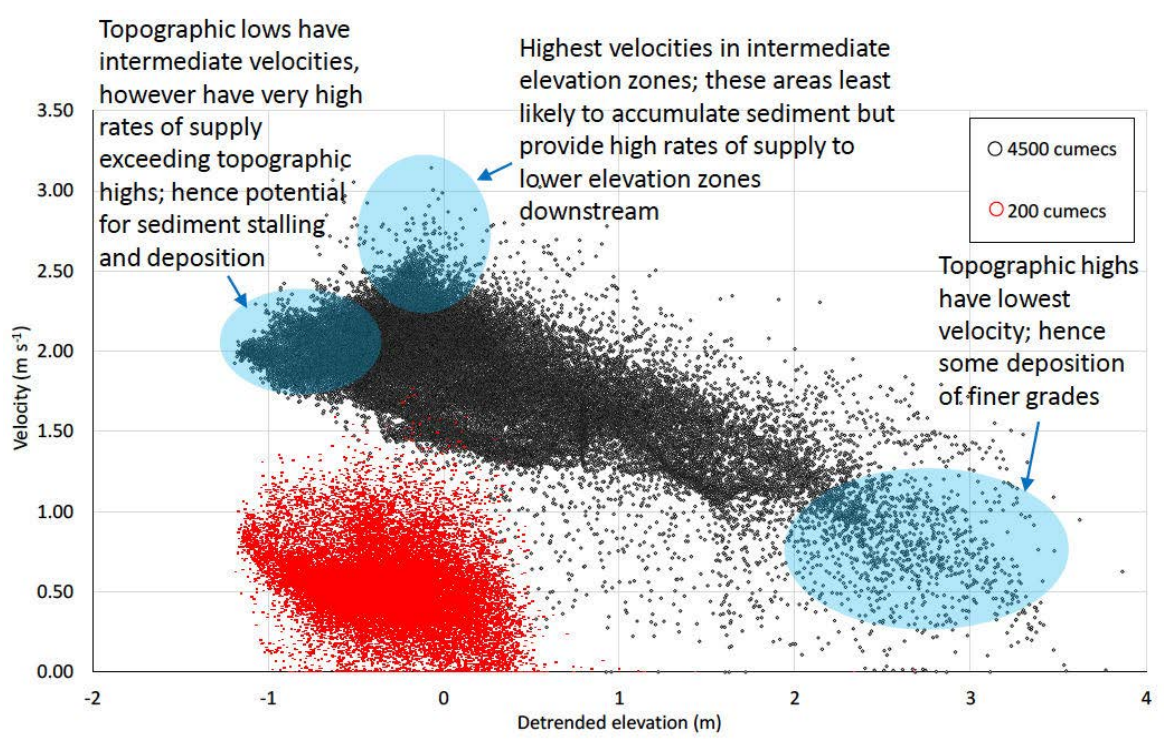

Figure 4. Velocity data taken from the same $5 \mathrm{~m}$ pixels as the sediment thickness data (Fig. 3 ): for low discharge (red: $\left.200 \mathrm{~m}^{3} \mathrm{~s}^{-1}\right)$, and high discharge (black: $4500 \mathrm{~m}^{3} \mathrm{~s}^{-1}$ ).

\subsection{Topographic controls on velocity patterns}

To explore the controls of topography upon flow hydraulics, depth averaged velocities for the same $5 \mathrm{~m}$ pixels used to derive the sediment thickness data were extracted for a competent but relatively low flow discharge of $200 \mathrm{~m}^{3} \mathrm{~s}^{-1}$ and a high flow of $4500 \mathrm{~m}^{3} \mathrm{~s}^{-1}$. These discharges are representative of the typical range of floods that occur on decadal timescales, during which net sedimentation (as opposed to net erosion) occurs. The relationship between topography and simulated depth-averaged velocities was investigated for these different flow conditions (Fig. 4). During the high flow $\left(4500 \mathrm{~m}^{3} \mathrm{~s}^{-1}\right)$, topographic highs are only just submerged and have the lowest velocity $\left(<1 \mathrm{~m} \mathrm{~s}^{-1}\right)$, which is likely to promote deposition of fine sediment. The highest velocities $\left(2-3 \mathrm{~m} \mathrm{~s}^{-1}\right)$ are found for intermediate elevation zones; these areas are least likely to accumulate sediment but probably facilitate sediment supply to lower elevation zones downstream. Topographic lows also have moderate velocities $\left(\sim 2 \mathrm{~m} \mathrm{~s}^{-1}\right)$, which are capable of entraining sand and even gravel clasts if available, so are not likely to accumulate fine sediment during peak flows. For the low flow $\left(200 \mathrm{~m}^{3} \mathrm{~s}^{-1}\right)$, topographic highs are exposed, with no flow occurring over these areas (Fig. 4). Velocity reductions are dramatic as discharge falls, most notably in lower topographic zones (Fig. 4), which promotes rapid deposition of fines and infilling of bedrock hollows. The intermediate elevation zones are submerged at low flow and have a similar velocity range to lower elevation areas. Most of the flow is concentrated into the topographic lows, however, where sediment is likely to be routed and reworked, but with deposition occurring in lower energy areas.

\section{Discussion}

Heritage et al. (2014) have presented OSL dates for the KNP rivers that suggest extensive flood-related stripping events tend to occur on centennial timescales. In between these extreme flood events, sediment builds up over the stripped bedrock template during lower magnitude flows. Our modelling and field observations indicate that during these lower magnitude flows, sediment is initially deposited rapidly as flood discharge falls (Fig. 5a), predominantly in topographic lows (Fig. 5b) where some sediment may be sheltered from erosion in subsequent floods. These findings represent a refinement to van Niekerk et al.'s (1999) more generalised conceptual model that assumed near-uniform, ubiquitous sedimentation over bedrock highs, and are supported by the flume investigations of Hodge and Hoey (2016). An additional field observation is that fine sediment (e.g. silt) that is deposited away from the low flow channel network may be eroded by rainfall, and reworked into topographic lows (Fig. 5c). This augments the flood deposits and helps promote colonisation by early successional vegetation such as Phragmites mauritianus.

Once vegetation establishes, then the sediment unit is strengthened owing to the development of root structures. Vegetation also helps to trap sediment and propagules supplied from upstream, encouraging further alluviation and plant growth. For instance, growth of Breonadia salacina in bedrock discontinuities and later successional Combretum spp. and Syzgium guineense enables the capture of organic material during floods and provides potential for further vegetation development from these nuclei. Sediment thicknesses are likely to develop further in what were originally bedrock 


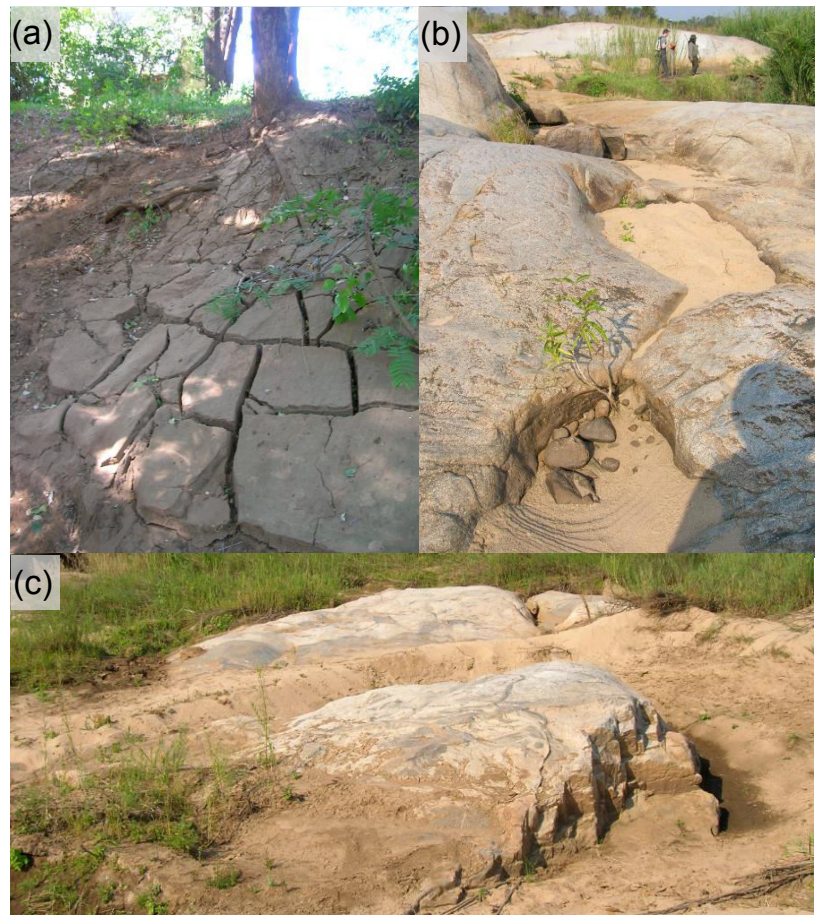

Figure 5. Sediment deposition patterns on the Olifants River in the Kruger National Park: (a) post-flood peak silt drapes (flow direction from left to right); (b) sand accumulation in topographic lows (flow direction from top to bottom); (c) sand deposition in topographic lows and areas in the lee of bedrock outcrop (flow direction from right to left). Silt deposition is also evident in the lee of the outcrop (see foreground), and in the stoss side hollow, possibly owing to reworking from the topographic high by rainfall.

topographic lows, eventually leading to bedrock core bars and islands, with the alluviated high loci situated over the bedrock topographic low loci. In this way, many of the bedrock low points have the thickest and wettest substrate for plant development, and are less susceptible to complete stripping during large floods. Field observations based on "before" and "after" comparisons of extreme floods (Milan et al., 2017) show that many topographic highs have a tendency to be stripped during flood events capable of submerging these areas. We intend to further test these hypotheses through running more simulations on other sites with different channel types, and also using repeat LiDAR data for sites that were stripped in the 2012 event.

\section{Conclusions}

1. Barforms are initiated by sediment deposition that occurs over preferentially in bedrock topographic lows. These lows display mid-range velocities during the peak of high flow events, but tend to be preferential routing zones for sediment, with deposition occurring in low energy areas on the falling limb of floods;
2. Although some initial deposition of fine sediment can occur on topographic highs following floods, some may be reworked into topographic lows by rainfall;

3. Vegetation development is likely to be fundamental to subsequent barform and island growth as it increases the cohesive strength of sediment and captures additional sediment and propagules, but this needs to be tested by additional modelling work.

Data availability. The authors do eventually intend to make the LiDAR data available through the NERC data repository.

Competing interests. The authors declare that they have no conflict of interest.

Special issue statement. This article is part of the special issue "Water quality and sediment transport issues in surface water". It is a result of the IAHS Scientific Assembly 2017, Port Elizabeth, South Africa, 10-14 July 2017.

Acknowledgements. This project was funded through the Natural Environment Research Council Urgency Grant NE/K001132/1. We would like to thank SANParks for supporting this research.

Edited by: Gil Mahe

Reviewed by: Jens Turowski and Rebecca Hodge

\section{References}

Baker, V. R.: Stream-channel response to floods, with examples from central Texas, Geol. Soc. Am. Bull., 88, 1057-1071, 1977.

Coulthard, T. J., Neal, J. C., Bates, P. D., Ramirez, J., Almeida, G. A., and Hancock, G. R.: Integrating the LISFLOODFP 2D hydrodynamic model with the CAESAR model: implications for modelling landscape evolution, Earth Surf. Proc. Landf. 38, 1897-1906, 2013.

Heritage, G., Tooth, S., Entwistle, N., and Milan, D.: Long-term flood controls on semi-arid river form: evidence from the Sabie and Olifants rivers, eastern South Africa, Proc. IAHS, 367, 141146, https://doi.org/10.5194/piahs-367-141-2015, 2014.

Heritage, G. L., Moon, B. P., Jewitt, G. P., Large, A. R. G., and Rountree, M.: The February 2000 floods on the Sabie River, South Africa: an examination of their magnitude and frequency, Koedoe, 44, 37-44, 2001.

Heritage, G. L., Large, A. R. G., Moon, B. P., and Jewitt, G.: Channel hydraulics and geomorphic effects of an extreme flood event on the Sabie River, South Africa, Catena, 58, 151-181, 2004.

Heritage, G. L., Entwistle, N., Milan, D. J., and Tooth, S.: Estimating flood magnitude using a 2D modelling approach: examples from the Sabie and Olifants rivers, eastern South Africa, Catena, in review, 2017. 
Hodge, R. A. and Hoey, T. B.: A Froude-scaled model of a bedrock alluvial channel reach: 2 . Sediment cover, J. Geophys. Res.-Earth Surf., 121, 1597-1618, 2016.

Kale, V. S., Baker, V. R., and Mishra, S.: Multi-channel patterns of bedrock rivers: an example from the central Narmada basin, India, Catena, 26, 85-98, 1996.

Milan, D. J., Heritage, G. L., Tooth, S., and Entwistle, N.: Morphodynamics of bedrock-influenced dryland rivers during extreme floods: insights from the Kruger National Park, South Africa, Geol. Soc. Am. Bull., in review, 2017.

Nanson, G. C.: Episodes of vertical accretion and catastrophic stripping: a model of disequilibrium flood-plain development, Geol. Soc. Am. Bull. 97, 1467-1475, 1986.

Rountree, M. W., Rogers, K. H., and Heritage, G. L.: Landscape state change in the semi-arid Sabie River, Kruger National Park, in response to flood and drought, South African Geographical Journal, 82, 173-181, 2000.
Tooth, S.: Changes in fluvial systems during the Quaternary, edited by: Knight, J. and Grab, S., Quaternary Environmental Change in Southern Africa: Physical and Human Dimensions, Cambridge University Press, 170-187, 2016.

van Niekerk, A. W., Heritage, G. L., and Moon, B. P.: River classification for management: the geomorphology of the Sabie River, South African Geographical Journal, 77, 68-76, 1995.

van Niekerk, A. W., Heritage, G. L., Broadhurst, L. J., and Moon, B. P.: Bedrock anastomosing channel systems: morphology and dynamics in the Sabie River, Mpumalanga Province, South Africa, edited by: Miller, A. J. and Gupta, A., Varieties of Fluvial Form, John Wiley and Sons, 219-247, 1999. 